\title{
Approaches to Building Teacher-Parent Cooperation
}

Franc Cankar ${ }^{* 1}$, Tomi Deutsch² and Sonja SentočniK ${ }^{3}$

$\approx$ The purpose of this study was to explore the areas of cooperation in which parent and teacher expectations were the same and where they differed. Data were obtained from a sample of 55 randomly selected primary schools. We analyzed school-to home communications, parental influence on school decisions, and parent involvement in different school activities. At the same time, we also explored building cooperation among the teachers, students, and their parents, within the framework of the program 'Reading and Conversation'. The findings indicated that the third-and ninth-grade lead teachers were mostly in agreement about the importance of parent involvement and as such represented a fairly homogenous group. The third-grade lead teachers were more open about actual involvement of parents in instruction than their ninth-grade colleagues, who were more cautious and restrained. In contrast to the lead teachers who represented a relatively narrow professional group, parents' views were much more diverse. Parental education was the best predictor of their readiness to become involved in the life and work of their children's school. Whether the area in which the families lived was urban or suburban did not make any difference. The evaluation of the one-year 'Reading and Conversation' programme revealed increases in parents'motivation to collaborate with the school as a consequence of the program's approach to work, as well as improvement in mutual relationships and dialogue.

Keywords: Parents, Primary school, School-to-home communications, Teachers

${ }^{*}$ Corresponding author. The National Education Institute, Slovenia, Poljanska 28, 1000 Ljubljana franc.cankar@zrss.si

2 The National Education Institute, Slovenia tomi.deutsch@zrss.si

3 Lehigh University, Bethlehem, PA, USA sonja.sentocnik@gmail.com 


\section{Pristopi k oblikovanju sodelovanja med učitelji in starši}

Franc Cankar ${ }^{*}$, Tomi Deutsch in Sonja Sentočnik

$\propto$ Namen študije je bil raziskati področja sodelovanja, na katerih se pričakovanja učiteljev in staršev ujemajo in razlikujejo. Podatki so bili pridobljeni na vzorcu 55 naključno izbranih osnovnih šol. Analizirali smo področja komunikacije med šolo in domom, vpliv staršev na odločitve šole in vključevanje staršev v različne šolske dejavnosti. Hkrati smo proučili tudi oblikovanje sodelovanja med učitelji, učenci in njihovimi starši v okviru programa »Branje in pogovor» (»Reading and Conversation«). Ugotovitve kažejo, da se učitelji tretjega in devetega razreda večinoma strinjajo glede pomembnosti vključevanja staršev in tako predstavljajo precej homogeno skupino. Učitelji tretjega razreda so bili bolj odprti glede dejanskega vključevanja staršev v pouk kot njihovi kolegi v devetem razredu, ki so glede tega previdnejši in bolj zaprti. $\mathrm{V}$ nasprotju z učitelji, ki predstavljajo precej ozko skupino strokovnjakov, se mnenja staršev veliko bolj razlikujejo med seboj. Glede na izobrazbo staršev se je dalo najbolje napovedati njihovo pripravljenost za vključevanje v delo in življenje šole, ki jo obiskujejo njihovi otroci. Razlike med mestnim in primestnim okoljem niso bile zaznane. Evalvacija enoletnega programa »Branje in pogovor « je pokazala dvig motivacije staršev za sodelovanje s šolo zaradi programskega pristopa k delu. Ugotovljen je bil tudi napredek v medsebojnih odnosih in dialogu.

Ključne besede: učitelji, starši, komunikacija med šolo in domom, osnovna šola 


\section{Introduction}

The development of society in the recent decades has been fraught with rapid social, economic, and political change, which has created feelings of uncertainty in people's lives. People were not so exposed to such change in the past; they were able to adapt to the social circumstances that guided their lives without much risk. Today things have changed, and people have to take greater responsibility for their own lives. The same applies to the family and school. A child's experience of schooling often depends on the connections between his family and social environment, and on welfare in case of families at risk.

Numerous factors influence the development and quality of the relationship between family and school. The nature of cooperation depends on the local tradition and culture as well as socio-economic status of school district. In addition, what kind of school the child attends, his teachers' professional knowledge, school leadership, parent education and their aspirations and ambitions are all important. The quality of cooperation can differ from school to school. Research has shown that the inclusion of family contributes to better educational outcomes, improves attendance and increases students' responsibility for fulfilling school obligations (Catsambis \& Beveridge, 2001; Simon, 2004). Catsambis and Beveridge (2001) confirmed that lower socio-economic status contributed to lower educational outcomes; however, the influence of socio-economic status was neutralised in high school with the inclusion of parents. If the communication between teachers and families is regular and transparent, students' attendance improves and chronic absence decreases over the years (Epstein et al., 2004; Sheldon \& Epstein, 2002). A study of the influence of teaching strategies on student achievement produced similar findings. If teachers designed homework in such a way that they encouraged interactions of students with their parents, the number of students who had better results at mathematics increased. Systematic inclusion of families and local communities into the activities that were focused on student behaviour improved discipline (Sheldon \& Epstein, 2002). Epstein (2001) suggests three key aspects of relationships between family and school. These are separated, shared and sequential responsibilities of schools and families. The first perspective assumes that the school and family fulfil their goals separate from each other. In contrast to this perspective is shared responsibility, which emphasises complementarity, cooperation, and communication between the institutions, asserting that the school and family share their responsibility for their children's socialisation, and education. Teachers and parents believe that they are more effective if they pursue those goals together. The third perspective emphasises the sequential responsibility of institutions, and exposes the importance of 
early stages of childhood development for his later success in school. The author of this paper (Epstein, 2001, p. 28) developed a model of overlapping spheres of influence of family and school on students' learning and development, and on family and school effectiveness.

Although some authors consider school, family, and community partnerships an illusion (Jowett et al., 1991), family and community involvement in education has become essential for successful living together. This issue is related to the nature of successful communities and the nature of human achievement in general. 'Nobody educates others, and we do not educate ourselves. We educate each other in a community, in the living environment of this world' (Hopkins, 2007, p. 13). This is exactly what the school-family relationship is about. The English sociologist Furedi (2008) shares this opinion. He sees the school as a city in which people meet and communicate, and in which change can happen. It goes without saying that the ideas related to the question of culture have to be implemented in the spirit of respect for plurality. Consequently, schools and teachers need to pay more attention to the development of a culture of living together.

In Slovenia, we have evaluated and changed certain elements of education system in the previous decade; however, we do not have sufficient empirical evidence to make claims about the problems related to family and school cooperation. One of the key questions refers to the quality of partnership between these two institutions. If we want to determine the level of quality of school and family partnership, we need to define the criteria for quality appraisal by taking into account a sensitive combination of different factors. Total quality consists of objective and subjective qualities (Snoj \& Mumel, 2001, p. 123). The former is based on certain standards, and the latter depends on the consumer's subjective perception of the quality of service. Because the quality of cooperation is always a subjectively expressed individual perception, determining the level of quality is extremely difficult and demanding. The quality of school and family cooperation is not simply reflected in objective reality but is also an expression of feelings. The feelings of teachers and parents reflect the emotional relationship between them and their construction of reality. The quality of their cooperation is therefore determined by the presence of mutual agreement and how much it is harmonised. The school's planning of guidelines for family and school cooperation is usually based on the assumption of a shared value system. However, if common values are not 'internalised', which means that parents and teachers do not consider them as part of their value system, the foundation for initial harmony is missing (compare Bučar, 2003). Without common agreement, it is virtually impossible to direct a system. The system lacking initial common agreement is always in crisis; it lacks the agreement about a desirable state that would make cooperation meaningful. 


\section{Purpose and Goals of the Study}

The purpose of our study was to explore the approaches to establishing cooperation between lead teachers and parents of third and ninth grade primary students, and the quality of that cooperation. The study also sought to find differences and similarities in parent and teacher expectations within different areas of their cooperation. At the same time, we tried to determine if the teachers', parents' and students' collaboration in the 'Reading and Conversation' programme contributed to their better relationships and partnership. We set the following goals:

- $\quad$ To estimate the degree to which the expected cooperation and actual cooperation were in agreement between groups of parents and teachers of the third- and ninth-grade primary students;

- To enquire into the interconnectedness of latent dimensions of parents' cooperation with the school, such as their sex, education, participation in formal school events, and location of their home.

- To determine if the programme 'Reading and Conversation' improved the cooperation between school and family.

\section{Methods}

Data were obtained from a sample of 55 randomly selected primary schools in the 2006/2007 academic year, specifically from their 141 third- and ninth-grade lead teachers ( 78 third-grade lead teachers, and 63 ninth-grade lead teachers), and 810 randomly selected parents of the students from the selected schools (399 parents of the third-grade students and 411 parents of the ninthgrade students) who were included in the survey.

The survey was conducted in such a way that we visited each school in the sample, and distributed the questionnaires for the lead teachers and for the parents, together with instructions and a list of selected students to the thirdand ninth-grade lead teachers from the sample. The lead teachers distributed the questionnaires for the parents to the students who then took them home to their parents. The lead teachers filled in the questionnaires during our visit and returned them personally to the visitors. For the lead teachers who were absent or for those that taught in dislocated units, as well as for the parents of the students of those teachers, a self-addressed stamped envelope was mailed to them together with the questionnaire.

A total of 368 questionnaires were returned from the parents of the $3 \mathrm{rd}$ and 9 th grades (170 from the parents of the 3 rd graders, and 198 from the parents of the 9 th graders), and 134 questionnaires were returned from the lead teachers 
(75 from the 3 rd grade lead teachers, and 59 from the 9 th grade lead teachers). The survey return rate was thus $45.5 \%$ from parents, and $95.0 \%$ from lead teachers.

Two separate questionnaires were used for the collection of survey data, one for the parents and one for the lead teachers. The questionnaires were designed so that the statements in basic sets were the same for parents and lead teachers. When designing the questionnaires, we partly used the existant instruments of different authors (Crozier, 2000; Kolar, 2005; Medveš et al., 2001; Sheldon \& Epstein, 2002). The questionnaires included all the key areas of our research: school-to-home communications (using eight indicators and measuring how well the parents' were informed about the school and its operation ${ }^{\mathrm{i}}$ ), influence (using eleven indicators and measuring parent and teacher influence on

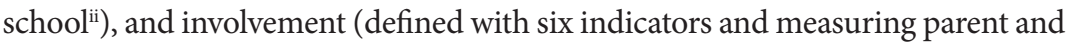
teacher involvement in the learning process ${ }^{\mathrm{iii}}$ ). In addition, we also conducted a focus interview with eight 9 th grade teachers, included in the survey. We asked them to describe the constraints to their collaboration with parents.

Initially, basic descriptive statistics were calculated for all the variables used in the study using the standard procedures. Next, we compared the answers of both groups of teachers and both groups of parents, as well as those of parents and teachers. Chi-square and t-tests were used for determining the statistical significance of the differences. The effects of independent variables were ascertained by means of regression analysis. For basic sets of variables, the data structure was checked by means of the principal component method and factor analysis (maximum likelihood estimation and principal axis factoring). Teachers' statements from the interview that best define the research problem are included in the results.

For each area, we measured how important that area was for the interviewees (Importance) and what the actual situation in that particular area was (Actual). Because we measured 'the importance' of individual areas and 'the actual situation' for each area in different ways, we transformed the collected data to the same interval (from zero to one) in order to achieve a higher degree of comparability; in the case of 'importance', we transformed average values, which were calculated based on a five-level scale, from the interval one to five to the interval zero to one. In this way, we achieved comparability of the importance of the area with the average value of the actual situation for the area, which was originally calculated on the interval from zero to one due to input data (average value of activity performance for the area).

The programme 'Reading and Conversation', in which 11 fifth grade students, their parents, and their lead teacher participated, lasted for a year (Kolar \& Kušar, 2009). Partner meetings occured once a month. The meetings were 
focused on reading books and discussing their content around the following topics: celebrations, diversity, tolerance, intergeneration contacts, and life messages. The students, parents, their lead teacher and the librarian selected the books and prepared the programme (action plan), which also included the motivational strategies for collaboration of all participants in the project. The programme evaluation was based on the methodology of action research and qualitative analysis.

\section{Results}

\section{Agreement between Groups of Parents and Lead Teachers}

Parents and lead teachers of third- and ninth-grade primary students agreed that cooperation was beneficial for their children/students. They both considered that it was imporant for the students to gain good education in school. Parents did not perceive cooperation with school as a burden. They both agreed that school-to-home communications were the key to good cooperation (Table 1). Table 1 contains average values, calculated based on the transformed (standardised) scales. In the case of importance, value o is not important, and value 1 is very important. In the case of actual condition, value o means not true at all, and value 1 means absolutely true.

Table 1: Comparison of Expected Importance and Actual Situation (parents, lead teachers)

\begin{tabular}{|c|c|c|c|c|c|c|}
\hline \multirow[b]{2}{*}{ Population } & \multicolumn{3}{|c|}{ Importance } & \multicolumn{3}{|c|}{ Actual } \\
\hline & 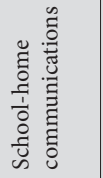 & 苞 & 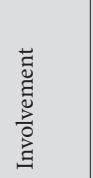 & 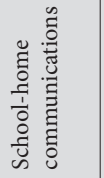 & 节 &  \\
\hline Parents ( $3^{\text {rd }}$ grade $)$ & 0.858 & 0.636 & 0.507 & 0.693 & 0.393 & 0.405 \\
\hline $\begin{array}{l}\text { Lead teachers } \\
\left.\text { ( } 3^{\text {rd }} \text { grade }\right)\end{array}$ & 0.873 & 0.626 & 0.652 & 0.920 & 0.584 & 0.772 \\
\hline Parents ( $9^{\text {th }}$ grade) & 0.827 & 0.653 & 0.489 & 0.687 & 0.340 & 0.337 \\
\hline $\begin{array}{l}\text { Lead teachers } \\
\left.\text { ( } 9^{\text {th }} \text { grade }\right)\end{array}$ & 0.870 & 0.658 & 0.596 & 0.923 & 0.646 & 0.661 \\
\hline $\begin{array}{l}\text { Differences between } \\
\text { Parents and Lead teach- } \\
\text { ers in } 3^{\text {rd }} \text { grade; } t \text { (sig.) }\end{array}$ & $\begin{array}{r}-1.029 \\
(0.305)\end{array}$ & $\begin{array}{r}0.476 \\
(0.634)\end{array}$ & $\begin{array}{r}-5.910 \\
(0.000)\end{array}$ & $\begin{array}{r}-8.432 \\
(0.000)\end{array}$ & $\begin{array}{r}-5.377 \\
(0.000)\end{array}$ & $\begin{array}{r}-9.683 \\
(0.000)\end{array}$ \\
\hline $\begin{array}{l}\text { Differences between } \\
\text { Parents and Lead teach- } \\
\text { ers in } 9^{\text {th }} \text { grade; } t \text { (sig.) }\end{array}$ & $\begin{array}{r}-2.321 \\
(0.021)\end{array}$ & $\begin{array}{r}-0.254 \\
(0.800)\end{array}$ & $\begin{array}{r}-4.105 \\
(0.000)\end{array}$ & $\begin{array}{r}-8.793 \\
(0.000)\end{array}$ & $\begin{array}{r}-10.010 \\
(0.000)\end{array}$ & $\begin{array}{r}-8.221 \\
(0.000)\end{array}$ \\
\hline
\end{tabular}


Individual indicators used to measure this area showed that parents and third-grade lead teachers rated especially highly the importance of mutual communication and conversation about their children's progress in school, their reaching or not reaching the expected outcomes, and problems they may have in school. Parents differed in their claims about the information they received regarding the areas in which their children were either meeting or exceeding the expectations. The parents of third-grade students differed from the parents of ninth-grade students in their views of the importance of receiving information about their rights, and about changes in school work planned by school. The parents of younger children provided more positive rates in all their responses.

Both groups of parents and lead teachers agreed that school-to-home communications were appropriate. Greater discrepancies occurred in their responses with regard to the form of communication, such as the school's web page, brochures, e-mail, and lead teacher's home visit. There were also discrepancies between the third- and ninth-grade parents and lead teachers in their actual perceptions of school-to-home communication (Table 1). The discrepancies are statistically significant in most of individual indicators used for measuring the actual degree of communication. The third-grade teachers were much more optimistic about the provision of information to parents regarding the areas in which their children were either meeting or exceeding the expectations. The same applied to the school rules and regulations that the parents needed to be acquainted with. There was a great discrepancy between both groups in actual provision of information to the parents about the possibilities of exercising their own and their children's rights. The third-grade parents were much more critical in comparison to the third-grade lead teachers: $36 \%$ of the parents claimed that they never received any information on the subject. The thirdgrade parents expressed similar criticism with regard to the planned changes of school work and their involvement in school activities. Statistically significant discrepancies occurred in how the ninth-grade lead teachers and parents perceived the actual communication in almost all the indicators. The parents were again much more critical than the lead teachers. The majority of the parents claimed that the lead teachers did not provide them with key information about their children's success in school.

A relatively high level of agreement occurred with regard to the importance that the third- and ninth-grade parents and lead teachers assigned to parental influence on school work (Table 1). Although both groups were fairly in agreement about parental influence on school work, the actual situation was quite different. The lead teachers maintained that parents actually influenced the work of school; $95 \%$ of the third-grade lead teachers, and $94 \%$ of the 
ninth-grade lead teachers agreed that they always consulted parents about the decisions that influenced student success in school.

The only statistically significant difference occurred in the statement about the school's consideration of parents' opinion about the broadening of the programmes; the third-grade lead teachers rated it much lower. Although the third-grade lead teachers maintained that parents could always express their opinion, the majority of parents did not agree with them. The statements about parent influence on the rules of student conduct in school and classroom also revealed an interesting situation. More than $45 \%$ of the lead teachers in our study claimed that parents could not exert any influence; $60 \%$ of the parents of both grades agreed with that claim, and $23 \%$ said that they did not know. The parents were therefore not only critical, but also not informed. The ninth-grade lead teachers and parents also significantly differed in their opinion in most of the indicators that define the possibility of their influence on school work. The opinions of both groups were rather polarised, with the parents being much more critical. Greater discrepancy occurred in the statement that the school asks parents for their opinion with regard to the activities for which they have to contribute financially; $62 \%$ of the parents stated that they could not influence the selection of additional and above-standard school services, and 59\% of the parents stated that they had no influence on defining the rules of student conduct. It is interesting that $36 \%$ of the lead teachers agreed with them.

Parents and teachers of the third- and ninth-grade students considered parent involvement in school work important, and they both verbally supported it: $76 \%$ of the third-grade lead teachers emphasised that parents could observe instruction, and only $50 \%$ of the ninth-grade lead teachers expressed the same opinion. Both groups agreed that parental involvement in various school activities was important. They also considered that it was important that the school invited parents to various formal or informal meetings.

In spite of the general support to parent involvement in various school activities, $80 \%$ of the parents of the third graders in our study had never visited classrooms to observe their children at work, and the situation was similar with the ninth-grade parents. There were significant differences between the two groups of parents in their involvement in their children's extracurricular activities, with the parents of younger students being more involved. The actual situation regarding parent involvement shows that more than $50 \%$ of parents from both groups cannot observe or assist teachers in the classroom, and more than $30 \%$ of parents from both groups do not know if they are allowed to be involved. The statement that parents can be involved in various school activities is barely statistically significant. The percentage is higher for the third-grade 
parents, but almost $50 \%$ of the ninth-grade parents stated that they did not have that opportunity. Nevertheless, the parents were invited to attend formal and informal meetings organised by the school. The data about parents' willingness to be involved in and contribute to the school work is interesting. Especially the ninth-grade parents rated moderately high their readiness to participate in the school councils. Both groups of parents expressed their readiness to be involved in school projects.

Teachers' statements from the interviews complement the empirical data, and provide additional information on the reasons why teachers formally support parent cooperation but are against it in reality:

- Cooperation with parents is important but the question is what kind of cooperation. It bothers me that some parents don't seem to be interested in their children's success in school. Sometimes their lack of criticism with regard to their children's achievement is problematic. Their expectations are often unrealistic.

- I like to collaborate with my students' parents. I think it's good that we talk and they tell me what their child is like at home and outside school. But I don't appreciate their interference with my work in the classroom. I'm frustrated when they let me know that they know as much about teaching as I do.

- That's what I think about collaboration with parents. They have enough opportunity for expressing their opinion at parent teacher meetings and at parent council meetings. But as far as their children's learning outcomes are concerned, they should do their work at home, and I'll do mine at school.

The above teachers' statements indicate that establishing partnership with parents is not without problems, the main being their perception of the cooperation with parents as that between professionals and laymen.

\section{The Influence of Independent Circumstances on}

\section{Assigning the Importance to School-to-Home Cooperation}

Common variables determining the quality of school-to-home cooperation, especially in primary school, are the sex of the parent, parental education, the frequency of parents' attendance of formal school events, and the location of their home. Each of these variables undoubtedly contributes to the quality of parental cooperation with lead teachers and with schools. Taking into account the structure of the approaches to parent cooperation with school, and the quality of that cooperation that we had determined, we used regression analysis to 
investigate the effect of parents' sex, education, attendance of formal school events, and the location of their home, on their expectations for their cooperation with school; therefore, the effect of these variables on the importance of schoolto-home communication, parental influence on school work, and the inclusion of parents in school activities.

The results show a connection between the approaches to parent and school cooperation in some of the independent variables (Table 2). In the table, standardised coefficients of the estimated regression model (Beta) are presented, and the statistical significance of the effect (sig.).

Table 2: The Influence of Sex, Education, and Location - Regression Analysis (parents)

\begin{tabular}{|l|r|r|r|}
\hline \multirow{2}{*}{ Independent Variables } & \multicolumn{2}{|c|}{ Dependent Variables } \\
\cline { 2 - 4 } & $\begin{array}{r}\text { School-home } \\
\text { communications (sig.) }\end{array}$ & Influence (sig.) & $\begin{array}{r}\text { Involvement } \\
\text { (sig.) }\end{array}$ \\
\hline Sex & $0.077(0.153)$ & $0.048(0.398)$ & $0.128(0.018)$ \\
\hline Education & $0.016(0.767)$ & $0.160(0.005)$ & $0.149(0.006)$ \\
\hline Parent Attendance & $0.129(0.017)$ & $0.054(0.338)$ & $0.143(0.008)$ \\
\hline Location & $0.066(0.224)$ & $0.041(0.471)$ & $-0.062(0.251)$ \\
\hline
\end{tabular}

In the area of school-to-home communications, the regression model fits the data well, although only $2 \%$ of the variability of dependent variable can be explained. Only parents' attendance of formal school events has a statistically significant effect on the importance of school-to-home communication, meaning that the parents who more often attend formal school events $($ Beta $=0.129)$ rate the importance of home-to-school communications higher.

The regression model also fits the data well in the area of influence, but (similarly to school-to-home communications) only $2.4 \%$ of the variability of dependent variable can be explained. In the case of influence, only parental education has a statistically significant influence on the importance of parent influence on school work, meaning that parents with higher education $($ Beta $=0.160)$ attribute more importance to parental influence on school work.

In the area of parental involvement in school work, $5 \%$ of the variability of the dependent variable can be explained using the regression model. All dependent variables have a statistically significant influence on the importance of parent involvement except for 'location'. Parent involvement in school work is rated higher by mothers $($ Beta $=0.128)$, parents with higher education $($ Beta $=0.149)$, and parents who more frequently attend formal school events $($ Beta $=0.143$ ). 


\section{Evaluation Results of the Programme 'Reading and Conversation'}

The data gathered from parents prior to the start of the 'Reading and Conversation' programme indicated that they mainly had positive experience with the family-school cooperation. Their answers indicating their positive experience can be summarised into the following categories: communication (relationships), advice, teacher activity, successful organisation, innovation, collaboration with school counsellor. The common categories of negative answers were: local community, grading, school leadership, relationships. Their most negative experience is connected with the school's collaboration with the local community, and a lukewarm attitude toward parent initiative on the part of the school administration.

The data gathered during the program were defined after coding as: relaxed atmosphere, teacher presence, opportunities for expressing different opinion, suitable content, getting to know each other, randomly selected groups, inclusion of all participants in the activities, collaboration, and surprise. The parents and students used the following expressions when talking about how they felt: nice, O.K., good, fun, tense, relaxed, excellent, super, nothing bothered us. 'Everything was O.K.' was a frequent note. Parental collaboration, their inclusion and attitude changed during the meetings, which can be inferred from authentic transcripts.

The findings indicate that the parents' attitude toward children and teachers changed. While at the beginning of the project, $45 \%$ of parents described negative experience in their cooperation with school; at the end of the project no one described any negative experience. The analysis showed a positive change in parent opinion in all areas. Here are some of their statements:

- I enjoyed the cooperation.

- I acquired a lot of new knowledge.

- I spent more time with my child.

- My cooperation benefits my child.

- I came to realise new things about my child.

- It's important for me to know that my child works with me in the same group.

- The meetings encouraged conversations with my child about other topic as well.

- My child tells me more about what happens in school now.

The parents therefore realised that they enjoyed their cooperation with school, that it helped them acquire new knowledge, and that they could get to know their children better. The majority of parents maintained that their 
cooperation in the program encouraged them to spend more time with their children, to get to know them better and talk with them more often.

\section{Discussion}

Why do teachers and parents represent two different worlds? How can differences in their views on the process of cooperation be explained? Why do they both agree that cooperation is important, but in practice their views differ? There are a number of reasons for this, with wider social reasons and arguments being the most decisive. As a professional group, teachers perform their work routinely within a defined framework, and cooperation with parents is part of their work. They are a rather homogenous group in their claim that their cooperation with parents is as it should be. They have high opinion about themselves and their work. As a relatively well-educated and professionally homogenous group, teachers have not been exposed to numerous risks as other professional groups have. For example, the risk that they may lose their job is lower, and it is harder to measure the effectiveness of their work. Consequently, they have not developed an awareness of the public character of their work that also includes their cooperation with parents. That is why they view this cooperation predominantly as an obligation that has to be performed, rather than as a partnership that needs to be developed for the sake of better quality of education that they provide for their students.

In contrast to teachers' views, which are rather homogeneous, parents' views are much more diverse. Parents are from different social groups, have different experience and expectations, and the success of their children in school varies. This is especially true of ninth-grade parents because ninth-grade-students' grades in certain subjects strongly determine the possibility of their enrolment in a secondary school of their choice, thus affecting their acquisition of good education and determining their future career path. Because they consider cooperation with school important, they have high expectations and are highly critical of school-to-home communications. Parental involvement in education is also starting to gain importance in Slovenia, (compare Rener, 200o, p. 109). In our survey, we included a parent who was more involved in their child's school work, and we found that mothers especially played a key role in providing support to their children ( $83 \%$ of surveyed parents were mothers). They were also the ones who expressed the need for better cooperation with their children's school.

Our findings suggest that parents' interest in their child's school success and development is the basis for their cooperation with school. Other authors have come to similar conclusions (Jowett et al., 1991; Resman, 1992). Because 
ninth-grade parents are especially interested in their children's school work, they are more critical of school-to-home communications, stating that schools do not inform parents well enough. The schools in our study used parent meetings (to provide information about the whole grade development to a group of parents) as the most typical form of school-to-home communication, followed by parent-teacher conferences (to provide information about an individual student to the parent). Other countries, e.g. Denmark, France, Germany, and Spain, show their preference for the same forms of communication (OECD, 1997). Parents obviously value individual and less-formal conversations with their child's lead teacher. Although parent-teacher conferences are a formal meeting, they offer an opportunity for informal parent conversation with their child's lead teacher about everything related to their child's school life (compare Marinšek, 2003; Resman, 1992; Wolfendale, 1989). Other forms of communication used in schools are various written instructions, e-mail notes, and phone calls. Although teachers and parents support teacher home visits as a rule, neither are really enthusiastic about them, with the parents and teachers of younger children being a bit more open to this form of school-to-home communication. The situation is similar in other countries (compare Kelley-Laine, 1998).

Frequent communication between lead teachers and parents is the key to the development of a trusting and responsible relationship between them. Sending messages and memos to parents from school is not enough. A teacher's visit at home is an opportunity for the development of a closer relationship, and for discussing children's progress at school in a more relaxed and informal way. However, teachers seem to have difficulties going beyond the traditional school framework, and parents still have negative feelings from the times of their own schooling, which is why they both feel reluctant about teachers' visits at home. Although teachers do occasionally visit a family, there is still much unused potential here. Lead teachers' visits at home, as a more frequent form of communication, could contribute to the development of honest communication between teachers and parents about their children and their school work.

The situation is similar with regard to parent involvement at the school. Parents' presence in the classroom is in itself somewhat controversial. There are arguments in favour of their presence, and there are others that are against it. Parents' presence in the classroom can take many forms. They can, for example, make a presentation to the class and thus make the instruction more interesting, they can assist an overworked teacher or recognise opportunities or embarrassing situations in the classroom. Their presence is also an opportunity for them to familiarise themselves with teachers' approaches to instruction, and to monitor their child's development (Resman, 1994; Vincent, 1996). Teachers, however, often perceive the presence of their students' parents as an additional pressure, 
increased responsibility, and more time for planning their instruction. They often doubt that parents have good intentions when they decide to be present during the instruction, and have general doubts about the presence of non-professionals in their classroom (Atkin et al., 1998; Mayall, 1990; Resman, 1994). Teachers maintain that teaching is an autonomous profession, and the majority of them are not enthusiastic about having parents in the classroom. They remain doubtful in spite of research findings that have confirmed the beneficial effects of parents' assistance to teachers in the classroom on both, teachers and students, which is especially true for younger students (OECD, 1997).

This problem should not be underestimated. New social conditions require the development of social skills that enable rapid adaptability to change, and consequently require from schools and teachers to go beyond their traditional framework and open up to the community so as to establish productive collaboration with its environment. It would therefore be advisable for schools and teachers to increase parent involvement and occasionally welcome parents' assistance in the classroom, because parents could add new and interesting perspectives to the topics covered in instruction. Many parents would probably be more than willing to work with teachers to improve instruction and connect it with real life, and would thus contribute to the development of a better classroom climate. However, this form of parent involvement does not seem to be taking hold in schools. It seems as if teachers consciously safeguard their position and hold parents at a safe distance from school by not including them in a 'critical' education group (compare Cankar \& Kolar, 2006; Vidmar, 2001; Vincent, 1996).

From the reasons stated above, teachers generally avoid inviting parents into the classroom. They do allow them to participate in less important activities, though, such as different administrative technical chores, and adult supervision in field trips (Mayall, 1990). Other researchers provide similar findings. Heywood-Everett (1999), for example, has found that teachers invite parents to be involved as partners in the activities that have no influence on school's effectiveness or its educational process. Although parents are invited to express their opinion about school work, they do not have any real influence on the development of school programs and policies. The situation is similar in the area of parent involvement in school governing bodies. Although the ninth-grade parents in particular rated their readiness to participate in school councils moderately high, those that become involved usually remain silent at the meetings because of their fear that they lack professional knowledge for valuable contribution (Cullingford, 1985; Deem et al., 1995). In addition, members of the school council often perceive themselves as an integral part of the decision-making body, rather than as the representatives of certain interest groups. This is especially true of the 
parents (Deem et al., 1995). The school council is often involved in promoting general school interests defined by the principal (Radnor \& Ball, 1996). A closer look at how parent and school councils are formed reveals that those parents that support the school and teachers are often identified as the potential school council members, and are then persuaded to accept their membership (Deem et al., 1995). We can probably conclude that the same is true for Slovenia. It is certainly true that our school councils rarely discuss topics related to the process of learning and teaching.

Over the years, teachers' cooperation with parents has increased, and parents have been regularly taking part in formal meetings organised by schools. Schools actively support and announce the importance of parent involvement and participation. However, it seems that teachers are not overly enthusiastic about putting their claims into practice. They perceive parents' involvement as an attempt to establish cooperation between professionals and non-professionals (Resman, 1992; Vincent, 1996). While they formally support parents' involvement, they also provide a number of arguments for keeping parents in a subordinate position.

It is not surprising that parents with higher education are more aware of the importance of good education for their children, and that they consequently consider parent influence on school work and life important. They indicate this view by being more interested in how their children spend their time in school, by actively seeking cooperation with school, asking questions and giving suggestions. We can safely assume that the parents, usually mothers, who are most frequently in touch with school, have better communication skills. Our finding that mothers are more involved in their children's education has been confirmed by other researchers (e.g., Cankar \& Kolar, 2006; Kolar, 2005; McNamara et al., 2000). This phenomenon has not received enough attention.

Whether parents live in suburban or urban environment does not bear any significance. This is not surprising, although it is important to take the establishment of cultural and evaluative relativism characteristic of our times into account when analysing social phenomena, and home location is no exception. Some authors (compare Gordon, 1985) do not consider individual social economic status when analysing the communication between teachers and parents, but rather include the quality of relationships stating that it does not depend on where people come from. Parents consider their involvement and participation in their children's school activities important, regardless of the environment in which they live. They all rate the importance of their children's education highly.

The analysis of the data gathered at the end of one-year cooperation with parents in the programme 'Reading and Conversation' shows that parent 
participation has a positive effect on their cooperation with school. Every participant evaluated their experience in the programme in a positive way. They especially valued trust, honesty, spontaneity and mutual understanding. It is important to note that the approach that was used in the programme, enabled parents to spend more time with their child in a group with other parents and children, and helped them develop new insights, as well as improve communication with their children at home.

\section{Conclusion}

The purpose of our study was to explore the approaches to establishing cooperation between lead teachers and parents of third- and ninth-grade primary school students, and the quality of that cooperation. The study also saught to find differences and similarities in parent and teacher expectations within different areas of their cooperation. The study focused on school-to-home communications, parent influence on school decisions, and parent involvement in different school activities.

Our findings indicate that the third- and ninth-grade teachers in our study represent a fairly homogenous group, and that their statements about the importance of the cooperation between school and home are mostly in agreement. The third-grade lead teachers are more open about actual involvement of parents in instruction than their ninth-grade colleagues who are more cautious and restrained. Both groups expressed similar opinion about the importance of parent cooperation in various school activities. The outcomes were similar for lead teachers and parents of both groups. They showed a high degree of agreement in their support to cooperation between teachers and parents. However, parents were a much more critical group in their perception of actual situation than lead teachers.

In contrast to the lead teachers, who represented a fairly narrow professional group, parents' views were much more dispersed. The lead teachers in our study felt uneasy in their communication with parents. Prominent reasons for that were parents' questions about their childrens' grades on one hand, and teachers' helplessness related to the limitsation of the institutional framework of the school system on the other.

Parental education was the best predictor of their readiness to get involved in the life and work of their children's school. This was especially the case with mothers who took part in formal school conferences more often than fathers. Whether the area in which the families lived was urban or suburban made no difference. All the parents in our study rated the importance of their 
children's education highly.

We conclude that the parents and teachers in our study are in agreement about the importance of cooperation between family and school. Both groups have similar expectations. Although the lead teachers consider school-to-home communication and parent involvement more important than the parents, there is not much discrepancy in their claims. However, the parents and teachers differ in their perceptions of the actual situation. The teachers' views of their cooperation with parents are much more optimistic than the parents. This is true for teachers and parents in general, and for the groups of the third- and ninth-grade teachers and parents.

When analysing the influence of parents' sex, education, attendance of formal school events, and the location of their home, we concluded that these variables did not have the same effect on how parents perceived their cooperation with school. Only parents' attendance of formal school events had a statistically significant effect on how the parents rated the importance of school-to-home communication, and only parental education had a statistically significant effect on how much importance they attributed to parent influence on school work. The parents' rating of the importance of parent involvement in school work was under the influence of their sex, education, and the frequency of their attendance of formal school events. Whether parents lived in suburban or urban environment did not bear any significance.

The findings related to the one-year programme 'Reading and Conversation', which was intended for the development of partnership between school and parents, confirmed that it was a useful way for motivating parents to cooperate with school, strengthening relationships among all three parties, and developing a high level of dialogue.

\section{Notes}

i The indicators used for parents/lead teachers: The lead teacher informs me about the areas in which my child is above average./As a lead teacher, I inform the parents about the areas in which their child is above average; The lead teacher informs me about the areas in which my child is below average./As a lead teacher, I inform the parents about the areas in which their child is below average; The lead teacher informs me about the problems my child experiences in school./ As a lead teacher, I inform the parents about the problems their child experiences in school; The school informs me about the rules and regulations I have to be familiar with as a parent./The school informs parents about the rules and regulations they have to be familiar with; The school informs me about the ways in which I can enforce my own and my child's rights./The school informs the parents about the ways in which they can enforce their own and their child's rights; 
The school informs me about the programme of additional and above standard activities./The school informs the parents about the programme of additional and above standard activities; The school informs me about any planned changes in future operation./The school informs parents about any planned changes in future operation; The school informs me about how I can participate in their activities./The school informs parents about how they can participate in their activities.

ii The indicators used for parents/lead teachers: The lead teacher includes me in the decisions that can affect my child's success./As a lead teacher, I include parents in the decisions that can affect their child's success; The school takes my suggestions into consideration in designing their extended programme (extra-curricular activities, camps, ...)./We take into consideration parent suggestions in designing our extended programmes (extra-curricular activities, camps, ...); The school seeks my advice when planning the activities that require my financial contribution./ The school seeks parent advice when planning the activities that require their financial contribution; The school asks for my written permission for the activities that require my financial contribution./The school asks for parent written permission for the activities that require their financial contribution; My suggestions and opinion are taken into consideration by a suitable school body./Parent suggestions and opinion are taken into consideration by a suitable school body; I can influence the selection of additional and above standard school activities./ Parents can influence the selection of additional and above standard school activities; I can always express my opinion to the school./Parents can always express their opinion to the school; I can influence rules about behaviour in school./Parents can influence rules about behaviour in school; I can influence rules about behaviour in the classroom./Parents can influence rules about behaviour in the classroom; I can influence the selection of textbooks and other didactic material in individual subjects./ Parents can influence the selection of textbooks and other didactic material in individual subjects; I can participate in the decisions that affect my child (selection of extra curricular activities, child participation in school events, ...)../Parents can participate in the decisions that affect their child (selection of extra curricular activities, child participation in school events, ...).

iii The indicators used for parents/lead teachers: I can be present at instruction. /Parents can be present at instruction; I can participate in instruction. /Parents can participate in instruction; I can be present at various school activities (extra curricular activities, camps, field trips, ...). /Parents can participate at various school activities (extra-curricular activities, camps, field trips, ...). I can participate in various school activities (extra-curricular activities, camps, field trips, ...). /Parents can participate in various school activities (extra-curricular activities, camps, field trips, ...). I get invitations to formal meetings in school./ Parents get invitations to formal meetings in school; I get invitations to informal meetings in school./ Parents get invitations to informal meetings in school. 


\section{References}

Atkin, J. et al. (1988). Listening to parents. London: Croom Helm.

Bučar, F. (2003). Porušena harmonija sveta. Ljubljana: MIS.

Cankar, F., \& Kolar, M. (2006). Lehrer und Eltern in Slowenischen Grundschulen -

Kooperationspartner mit unterschiedlichen Erwartungen. Empirische Pädagogik, 2o(4), 1-12.

Catsambis, S., \& Beveridge, A. A. (2001). Does neighborhood matter? Family, neighborhood, and school influences on eighth grade mathmaticks achivement. Sociological Focus, 34(4), 435-457.

Crozier, G. (2000). Parental Involvement: who wants it? International Studies in Sociology of

Education, 9(3), 219-238.

Cullingford, C. (1985). Parents, Teachers and Schools. London.

Deem, R. et al. (1995). Active Citizenship and the Governing of Schools. Buckingham: Open University Press.

Epstein, L. J. (2001). School, Family and Community Partnerships: Preparing educators and improving schools. Boulder, CO: Westview Press.

Epstein, J. L., \& Rodriguez Jansorn, N. (2004). Načrtovano partnerstvo šole in družine. The Education Digest, 69(6), 19-23.

Furedi, F. (2008). Levica se je prebarvala v zeleno: dr. Frank Furedi, angleški sociolog. Delo, Sobotna priloga (19.7.2008), 50(166), 21-23.

Gordon, T. (1985). Trening večje učinkovitosti za učitelje. Svetovalni center. Ljubljana.

Heywood-Everett, G. (1999). The Business of Learning: parents as full, unwilling or sleeping parents. International Studies in Sociology in Education, 9(3), 267-278.

Hopkins, D. (2007). Vsak učenec je pomemben - individualizirano učenje. Strokovno srečanje ravnateljic in ravnateljev OŠ. Portorož, November 2007.

Jowett, S. et al. (1991). Building Bridges: Parental Involvement in School. Windsor: NFER, Nelson.

Kelley-Laine, K. (1998). Parents as Partners in Schooling. Childhood Education, 74(6), 342-343.

Kolar, M. (2005). Komuniciranje med šolo in starši kot element kakovosti v vzgoji in izobraževanju.

Fakulteta za družbene vede. Ljubljana (magistrsko delo).

Kolar, M., \& Kušar, A. (2009). Program partnerskega sodelovanja. Zavod RS za šolstvo. Ljubljana.

Marinšek, S. (2003). Učitelji in starši: na istem ali na nasprotnem bregu. V A. Trnavčevič, Sodelovanje s starši - da, toda kako? (pp. 7-9). Ljubljana.

Mayall, B. (1990). Parents in Secondary Education. London.

McNamara, O. et al. (2000). Room to manoeuvre: mobilising the active partner in home school relations. British Educational Research Journal, 26(4), 473-487.

Medveš, Z. et al. (2001). Modro oko. Spoznaj, analiziraj, izboljšaj. Ljubljana: Zavod RS za šolstvo. Organisation for Economic Cooperation and Development (1997). Parents as partners in schooling. Paris: OECD.

Radnor, E., \& Ball, S. (1996). Local Education Authorities: Accountability and control. Stoke-on Trent: Trentham Books. 
Rener, T. (2000), Ranljivost, mladi in zasebno okolje. V Socialna ranljivost mladih (pp. 91-95).

Ljubljana: Ministrstvo za šolstvo in šport, Urad RS za mladino.

Resman, M. (1992). Partnerstvo med domom in šolo. Sodobna pedagogika, 43(3-4), 136-145.

Sheldon, S. B., \& Epstein, J. L. (2002). Improving Student Behavior and School Discipline with

Family and Community Involvement. Education and Urban Society, 35(1), 4-32.

Simon, B. S. (2004). High school outreach and family involvement. Social Psychology of Education,

$7(3), 185-209$.

Snoj, B., \& Mumel, D. (2001). Marketinški aspekti kvalitete usluga. Zagreb: Acta Turistica.

Vidmar, J. (2001). Sodelovanje med starši in šolo. Sodobna pedagogika, 52(1), 46-65.

Vincent, C., \& Tomlinson, S. (1996). Home-School relationships: The swarming of disciplinary

mechanisms? British Educational Research Journal, 23(3), 361-377.

Wolfendale, S. (1989). Parental Involvement: Developing Networks between School, Home and

Community. Oxford: Alden Press.

\section{Biographical note}

Franc Cankar is Head of the Center for Quality and Research at the National Education Institute Slovenia in Ljubljana. His research and development work is connected with the theoretical basis of school curriculum development and its implementation. He publishes on different topics in the area of education.

Tомг Deutsch is a senior adviser at the National Education Institute Slovenia. His research focuses primarily on the methodology and implementation of monitoring and evaluation of individual segments of education, as well as on the performance of basic research tasks. His development and research work covers all areas of pre-university education.

Sonja Sentočnik is a doctoral candidate at Lehigh University College of Education in Bethlehem, PA in the United States. Previously, she worked as a senior adviser and project leader at the National Education Institute, and participated in a number of transnational projects. Her research is primarily concerned with educational leadership and change agency, as well as professional learning of teachers and teacher educators. 